Original Article

\title{
THE ASSOCIATION BETWEEN WHO CLINICAL STAGE AND OTHER RISK FACTORS WITH PULMONARY TUBERCULOSIS AMONG PEOPLE LIVING WITH HIV/AIDS: A CROSS-SECTIONAL STUDY
}

\section{KETUT SURYANA ${ }^{1}$, HAMONG SUHARSONO², NOVIANA JOENPUTRI ${ }^{3}$}

1Department of Internal Medicine at Wangaya Hospital in Denpasar, Bali, Indonesia, ${ }^{2}$ Department of Biochemistry, Veterinary Faculty of Udayana University, in Denpasar, Bali, Indonesia, ${ }^{3}$ General Practitioner, Department of Internal Medicine at Wangaya Hospital in Denpasar, Bali, Indonesia

Email: ketutsuryana@gmail.com

Received: 20 Apr 2020, Revised and Accepted: 18 May 2020

\section{ABSTRACT}

Objective: To estimate the Pulmonary Tuberculosis (PTB) prevalence among the participants/People Living With HIV/AIDS (PLWHAs) and to verify the association between WHO clinical staging and other risk factors with PTB.

Methods: A cross-sectional study was conducted to estimate the PTB prevalence. Probable associated risk factors in PLWHAs with and without PTB were compared. The association between WHO clinical staging and other risk factors with PTB was investigated using bivariate analysis. A pvalue $<0.05$ was considered statistically significant.

Results: This study was conducted from January 2018 to December 2019, recruited about 584 participants with presumptive PTB and 20.72\% (121) confirmed with PTB. In the bivariate analysis; participants who are on human immunodeficiency virus (HIV) Stage 4 (WHO clinical staging) were significantly more likely to develop PTB $(\mathrm{p}=0.000)$. PTB was significantly higher among male than female $(\mathrm{p}=0.000)$, higher among the older $(\mathrm{p}=0.030)$. PTB was significantly more frequent among participants with lower cluster differentiation 4 (CD4) cell counts ( $\mathrm{p}=0.042)$. A contact history with a Tuberculosis (TB) patient was an important risk factor $(\mathrm{p}=0.000)$. PTB was significantly associated with smoking history ( $\mathrm{p}=0.000)$.

Conclusion: A high PTB prevalence was observed. There was a significantly association between the severity of WHO clinical staging, sex, age, lower CD4 cell count, a contact history with a tuberculosis (TB) patient and smoking history with PTB among PLWHAs.

Keywords: PLWHAs, WHO clinical staging, Associated risk factors, PTB

(C) 2020 The Authors. Published by Innovare Academic Sciences Pvt Ltd. This is an open access article under the CC BY license (http://creativecommons.org/licenses/by/4.0/) DOI: http://dx.doi.org/10.22159/ijpps.2020v12i7.37982. Journal homepage: https://innovareacademics.in/journals/index.php/ijpps

\section{INTRODUCTION}

World Health Organization (WHO) (2012) estimated 1.1 million new TB were found among people living with HIV/AIDS (PLWHA). TB is still as a leading cause of morbidity and mortality among PLWHAs, including those on highly active anti retroviral therapy (HAART) [1-3]. The coinfection of the human immunodeficiency virus (HIV) and PTB is one of a major public health problem worldwide [4,5]. HIV infection is associated with an increased of TB rate and with changed of clinical manifestations, especially in the advanced stages. PTB occurs in about $75 \%$ of all PLWHAs with TB [4]. The increasing rate of HIV infection is associated with an impact on TB epidemiology [6, 7].

A comprehensive strategy focusing on risk factors of TB is essential [8]. There is not enough data of the prevalence and various PTB risk factors among PLWHAs in our Hospital. The probable risk factors of PTB such as WHO clinical stage, sex, age, educational status, marital status, occupation, route of transmission, adherence to HAART, CD4 cell count, TB contact of the family and smoking history. The aim of this study is to estimate the prevalence of PTB and to verify the risk factors associated with PTB among PLWHAs who visited for assessing HAART.

\section{MATERIALS AND METHODS}

\section{Setting and study participants}

This study was conducted in PLWHAs, visiting Merpati clinic at Wangaya hospital in Denpasar, Bali, Indonesia for their eligibility of assessing HAART.

\section{Study design and data collection}

We conducted a cross-sectional study to estimate the prevalence of PTB and analysed the data comparing PLWHAs with PTB and without PTB, to verify the associated risk factors of PTB. The study team explained to participants; confidentiality assured, the anonymity of the collected data. An informed consent was obtained from all the participants. Information about age, sex, educational status, a history of TB contact, CD4 cell count, WHO clinical staging of HIV infection and others data was collected from participant medical records.

\section{Definition of study variables}

World Health Organization (WHO) PTB diagnostic criteria includes a clinical symptoms/TB screening and a Chest X-Ray suggestive of TB, mycobacterium tuberculosis (MTB) culture or Acid Fast Bacilli/AFB (sputum smear microscopy) when culture is unavailable [9].

In this study, the participants were adult PLWHAs who were confirmed PTB (positive clinical symptoms/TB screening, suggestive of TB on Chest X-ray and positive for Acid Fast Bacilli/AFB by direct microscopy or PLWHAs who had a prior data of medical record of being confirmed with PTB referral from other health-care facilities.

The case definitions and clinical staging of HIV/AIDS regarding to WHO are clinical stage 1 (asymptomatic) and stage 2-4 with a symptoms (acquired immune deficiency syndroms/AIDS) [10].

\section{Statistical analysis}

Descriptive test was performed to describe the participant characteristic data. Data were analyzed using SPSS version 18 and the data compared the participants with PTB and without PTB. Chi-square test was used to evaluate the association between risk factors with the prevalence of PTB. The significance of the variable associations are obtained in the bivariate analysis $(\mathrm{p}<0.05)$. 


\section{Ethics}

Ethical clearance was obtained No: 08/RSUDW/litbang/2018 from the local ethical committees. We collected data from the participants who visited Wangaya Hospital and completed at least two years follow-up from the ethical clearance granted to date.

\section{RESULTS}

A total of 584 PLWHAs were included in the study from January 2018 to December 2019. We found 121 (20.72\%) among 584 people living with HIV/AIDS were confirmed with Pulmonary Tuberculosis, are shown in fig. 1.

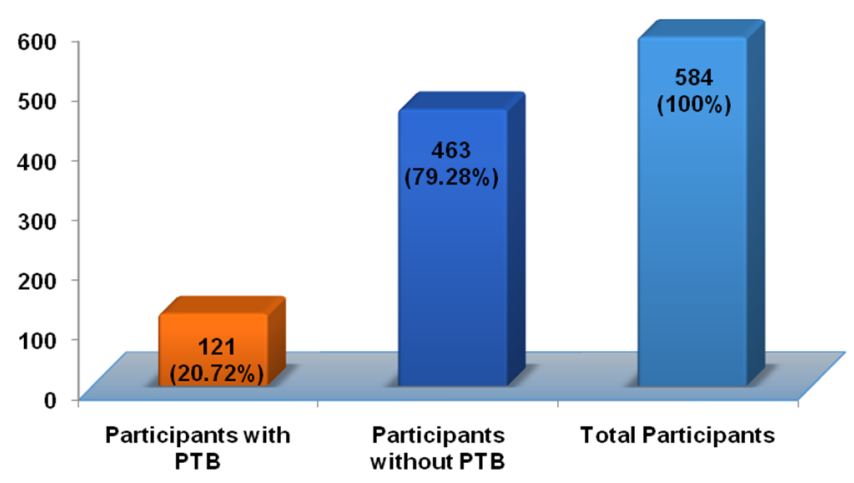

Fig. 1: The comparative data of participants

Among PLWHAs with PTB, 71.9\% were male, $61.2 \%$ were with the age $\geq 34$ y old, $83,5 \%$ were HIV stage 3 , the median of CD 4 cell count
(251 cells/ $\mu \mathrm{l})$ and $69.4 \%$ were with smoking history, are shown in table 1.

Table 1: Clinical and socio-demography characteristic of participants/PLWHAs with PTB (N=121)

\begin{tabular}{|c|c|}
\hline Variables & Total N (\%) \\
\hline \multicolumn{2}{|l|}{ WHO clinical staging } \\
\hline $\begin{array}{lll}- & 1 & 0\end{array}$ & 0 \\
\hline 2 & 0 \\
\hline 3 & $101(83.5)$ \\
\hline \multirow{2}{*}{\multicolumn{2}{|c|}{$20(10.5)$}} \\
\hline & \\
\hline Male & 87 (71.9) \\
\hline$-\quad$ Female & $34(28.1)$ \\
\hline Age: median of age: $34 \mathrm{y}$ & 34 \\
\hline$-\quad<34$ & $47(38.8)$ \\
\hline - $\quad \geq 34$ & $74(61.2)$ \\
\hline \multicolumn{2}{|l|}{ Educational status } \\
\hline - $\quad$ Elementary school & $10(8.3)$ \\
\hline Junior high school & $28(23.1)$ \\
\hline Senior high school & $66(54.5)$ \\
\hline - $\quad$ University & $17(14.0)$ \\
\hline \multicolumn{2}{|l|}{ Marital status } \\
\hline - $\quad$ Unmarried & $28(23.1)$ \\
\hline Married & 77 (63.6) \\
\hline - $\quad$ Divorced/widowed & $16(13.2)$ \\
\hline \multicolumn{2}{|l|}{ Occupation } \\
\hline - $\quad$ Yes & $107(88.4)$ \\
\hline$-\quad$ No & $14(11.6)$ \\
\hline \multicolumn{2}{|l|}{ Route of transmission } \\
\hline - $\quad$ IV drug user & $2(1.7)$ \\
\hline - $\quad$ Non-IV drug user & $119(98.3)$ \\
\hline \multicolumn{2}{|l|}{ Adherence to HAART } \\
\hline$-\quad$ Good & $117(96.7)$ \\
\hline - $\quad$ Poor & $4(3.3)$ \\
\hline CD4 cell count median (cells/ $\mu \mathrm{l})$ & 251 \\
\hline \multicolumn{2}{|l|}{ CD4 cell count $($ cells $/ \mu \mathrm{l})$} \\
\hline$-\quad<305$ & $56(58.9)$ \\
\hline - $\quad \geq 305$ & $39(41.1)$ \\
\hline \multicolumn{2}{|l|}{ Contact history with PTB patient } \\
\hline$-\quad$ Yes & $27(22.3)$ \\
\hline$-\quad$ No & $94(77.7)$ \\
\hline \multicolumn{2}{|l|}{ Smoking history } \\
\hline$-\quad$ Yes & $84(69.4)$ \\
\hline No & $37(30.6)$ \\
\hline
\end{tabular}

In bivariate analysis, the risk factors that significantly associated with PTB are male $(\mathrm{p}=0.000)$, PLWHAs with PTB are more likely to be older $(\mathrm{p}=0.030)$, more advance in WHO clinical staging $(\mathrm{p}=0.000)$, lower CD4 cell count $(\mathrm{p}=0.042)$, are prior with TB contact $(\mathrm{p}=0.000)$ and the majority with smoking history $(\mathrm{p}=0.000)$. All are shown in table 2 . 
Table 2: Bivariate analysis of participants/PLWHAs (N=584)

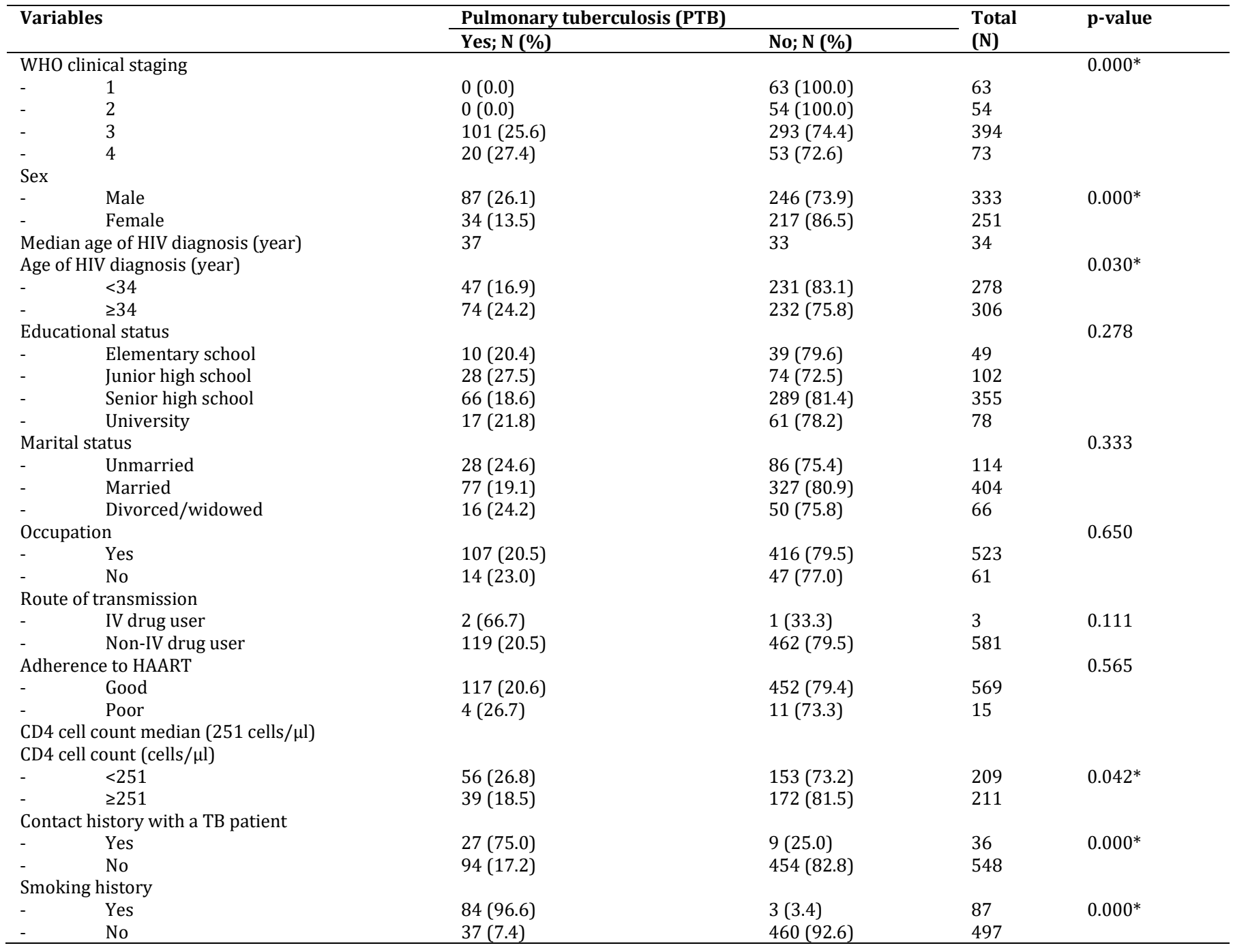

*bivariate analysis $(\mathrm{p}<0.05)$.

\section{DISCUSSION}

A cross-sectional study was carried out from January 2018 to December 2019, recruited PLWHAs with and/or without PTB.

HIV co-infection was the most potent immunodeficiency risk factor for developing Pulmonary tuberculosis [11].

This study found that among 584 total participants, 20.72\% (121 PLWHAs) were confirmed with PTB. The prior studies were reported wide range of the PTB prevalence among PLWHAs. Mama et al. (2018) reported, of the 291 PLWHAs screened, the overall PTB prevalence rate of $7.2 \%$ [12]. Negussie et al. (2018), found $36.9 \%$ of the study participants were confirmed PTB [13]; and Tiwari et al. (2019), reported a high prevalence of PTB was observed 32.4\% PTB [14].

We explored a WHO clinical staging and other risk factors by interviewing with a semistructured questionnaire and completed by data from the participant medical records.

In this study, PLWHAs with Stage 4 (WHO clinical staging) were more likely to develop PTB $(\mathrm{p}=0.000)$. Similar evidences were reported by Taha et al. (2011), that PLWHAs who with Stage 4 (WHO clinical staging) were more likely to develop PTB compared with Stage 3 (WHO clinical staging) (69.1\% vs 30.9\%; p<0.001) [8]. Kibret et al. (2013), found PTB patients were more likely to have baseline Stage 3 (WHO clinical staging) or Stage 4 (COR=4.51; 95\% CI: 3.032, 6.70) [15]. Belay et al. (2013), revealed that more than two-third of TB cases were in Stage 3 (WHO clinical staging) [16]. Roselinda et al. (2015), PLWHAs with Stage 4 (WHO clinical staging) were more at risk for developing PTB [17]. Awadalla et al. (2015), reported that PLWHAs with Late clinical WHO stages to be risk factors for developing PTB (AOR: 5.86; 95\% CI: 1.88-17.96; $\mathrm{p}<0.01$ ) [18]. Tesfaye et al. (2018), found a significant association between advanced WHO stage and TB-HIV/AIDS co-infection (OR: 6.81; 95\% CI: 3.91-11.88) [19].

We found a significantly association between the risk of developing PTB among PLWHAs with sex (male) was more likely $(\mathrm{p}=0.000)$. Carvalho (2008), also found that male was a high-risk factor for developing PTB [20]. It is unclear whether the more frequent in males due to the differences in social behavior. From a study conducted in South-western Uganda by Boum et al. (2014), they concluded TB prevalence was higher among male than female people with presumptive TB and it was independent of other TB risk factors [21]. Horton et al. (2016) concluded that TB prevalence was higher in men due to a disadvantage in seeking or accessing TB care in many settings [22]. One study by Dovonou (2017) in West Africa also showed that male gender was a potential risk factor of TB treatment failure [23].

The older age was more likely to develop PTB; this study found that the older participants were more frequent to develop PTB $(p=0.030)$. It is in accordance with a study by Keizer et al. Their prospective study showed age above $33 \mathrm{y}$ increased the risk for tuberculosis 
substantially [24]. Tiwari et al. (2019) reported PLWHAs with PTB were more likely to be older. A cross-sectional study in Iran also showed that adults and elderly comprised the highest proportion of TB [14]. Ghaffari-Fam (2015), their study showed that adults and elderly comprised the highest proportion of TB [25].

Our study found that PLWHAs had a very poor immune status. The median CD4 cell count was 251 cells/ $\mu$ l and was significantly associated with PTB ( $\mathrm{p}=0.042)$. Similar with other study, Chang et al. (2015) found that lower CD4 count was a high-risk factor for developing PTВ $(\mathrm{p}<0.01)$ [26], and Tiwari et al. (2012) reported that lower CD4 count was significantly associated with risk for developing PTB $(\mathrm{p}<0.001)$ [14]. The connection between risk of tuberculosis in HIV and low CD4 count was mentioned in a lot of study and most of them showed that a low CD4 count had a strong risk factor for the incidence PTB $[27,28]$. From a systemic review and meta-analysis by Ellis et al. (2017), an estimated a 1.43 fold increase (95\%CI: 1.16-1.77) in TB incidence per 100 cells $/ \mu \mathrm{l}$ decreased in CD4 cell count [29]. We revealed in this study, of total $71.08 \%$ of tuberculosis infection occurred in low CD4 level $(<80$ cells $/ \mu \mathrm{l}$ ) and from an analysis that CD4 below 80 cells $/ \mu \mathrm{l}$ had a significant association with a higher risk of tuberculosis infection (OR=6.043 95\%CI: 3.089-11.823) compared to CD4 count greater than 80 cells/ $\mu$ l. Belay et al. (2013) in their study conducted in Ethiopia stated that individual HIV cases whose CD4 count less than 200 cells $/ \mu$ l were more than seven times likely to develop tuberculosis compared to CD4 count more than 500 cells/ $\mu$ [16].

A retrospective study by Chang et al. (2015) in Nigeria also found that CD4 cell counts were significant predictors of TB, with CD4 cell counts $>350$ cells $/ \mu \mathrm{l}$ had one third the risk of developing TB compared with those with CD4 cell counts $\leq 100$ cells/ $\mu \mathrm{l}$ [26]. Sutariya et al. (2015), documented that lower CD4 count was strongly associated with the higher odds of PTB [27]. Sudre et al. (1996) reported that participant with CD4<50 cells $/ \mathrm{mm}^{3}$ were eight times more likely (AOR 7.8; 95\% CI 7.3-8.3) and those with 50-200 CD4 cells $/ \mathrm{mm}^{3}$ more than four times more likely (AOR 4.9; 95\% CI 4.4-5.4) to have tuberculosis than patients with CD4>500 cells $/ \mathrm{mm}^{3}$ [28].

This study found that a history of contact with a TB patient was significantly associated with PTB ( $\mathrm{p}=0.000)$. Taha et al. (2011), reported that the presence of TB patients in the family was significantly associated with PTB $(\mathrm{p}<0.001)$ [8]. Swarna (2014), in Malaysia found $30 \%$ of participants of pulmonary tuberculosis contact had positive tuberculin skin test (TST) compared to $53 \%$ of the participants without HIV infection [OR=0.41, 95\% CI 0.07-0.87; $\mathrm{p}=0.016][30]$.

Smoking history, this study found that smoking history was significantly associated with PTB $(\mathrm{p}=0.000)$. Other study by Kibret $e t$ al. (2013), also found that smoking history was more likely associated with PTB ( $\mathrm{p}<0.0001)$ [15]. Similarly, with Swarna (2014), reported that in Malaysia, the cigarette prevalence rate was high among participants with TB. Forty percent to fifty percent of TB participants were smokers and smoking prevalence was $57 \%$ of PTB [30]. Gjergji et al. (2018) reported that coinfection TB-HIV was more prevalent in smokers [31].

\section{CONCLUSION}

Most of PLWHAs having a poor clinical condition and the state of the immunity are reported to be predisposition factor of PTB. A high PTB prevalence among PLWHAs is observed. All PLWHAs should be screened for TB. In the presence of the risk factors, intensified screening is highly recommended. There is a significant association between the clinical severity of PLWHAs (WHO clinical staging), sex, age, lower CD4 cell count, a contact history with a TB patient and smoking history with PTB.

\section{LIMITATIONS}

This study is a hospital-based; thus the findings might not be generalizable. PTB diagnostic uses only smear microscopy of AFB staining. Microscopy is a less sensitive method compared with culture. The cultural technique is not performed because of the limited laboratory facilities.

\section{ACKNOWLEDGMENT}

The authors are grateful to: The study participants, Director of Wangaya Hospital, Denpasar, Bali-Indonesia, The Team members, Internist and all of the colleagues, Merpati Clinic staff who were support the study.

\section{FUNDING}

The authors declared that this study had received no financial support.

\section{AUTHORS CONTRIBUTIONS}

Ketut Suryana made substantial contributions to conception and design, acquisition of data, or analysis and interpretation of data; took part in drafting the article or revising it critically for important intellectual content; gave final approval of the version to be published; and agreed to be accountable for all aspects of the work. Hamong Suharsono took part in drafting the article or revising it critically for important intellectual content; gave final approval of the version to be published; and agreed to be accountable for all aspects of the work. Noviana Joenputrirevised it critically for important intellectual content; gave final approval of the version to be published; and agreed to be accountable for all aspects of the work

\section{CONFLICT OF INTERESTS}

No conflict of interest among the authors.

\section{REFERENCES}

1. Karo B, Haas W, Kollan C, Gunsenheimer-Bartmeyer B, Hamouda O, Fiebig L, et al. tuberculosis among people living with HIV/AIDS in the german clin surv HIV cohort: long-term incidence and risk factors. BMC Infect Dis 2014;14:1-12.

2. Ali A, Ahmad F, Imran M, Atif M, Noor Y, Imran S, et al. Prevalence of pulmonary tuberculosis in HIV/AIDS subjects. Austin Virol Retrovirol 2016;3:1023-5.

3. Ramamurthy $\mathrm{K}$, Bhat $\mathrm{S}$, Shenoy $\mathrm{S}$, Rangnekar A. Xpert mycobacterium tuberculosis/rifampicin assay: a boon in tuberculosis diagnostics. Asian J Pharm Clin Res 2016;9:225-7.

4. Cui Z, Lin M, Nie S, Lan R. Risk factors associated with tuberculosis (TB) among people living with HIV/AIDS: a pairmatched case-control study in Guangxi, China. PLoS One 2017;12:1-12.

5. Sawant DV, Desai MM, Patil RS, Pawar SH. Evolution of nantotech assisted PCR diagnosis of mycobacterium tuberculosis and its assessment with conventional methods. Int J Pharm Pharm Sci 2018;10:133-7.

6. Swaminathan S, Narendran G. HIV and tuberculosis in India. J Biosci 2008;33:527-37.

7. Mahtab S, Coetzee D. Influence of HIV and other risk factors on tuberculosis. South Afr Med J 2017;107:428-34.

8. Taha M, Deribew A, Tessema F, Assegid S, Duchateau L, Colebunders R. Risk factors of active tuberculosis in people living with HIV/AIDS in Southwest Ethiopia: a case-control study. Ethiop J Health Sci 2011;21:131-9.

9. WHO. Treatment of tuberculosis guidelines. 4th ed.; 2010. Available from: http/www.who.int/tb/publications/2010/ 9789241547833/en/. [Last accessed 04 Apr 2016].

10. Wolrd Health Organization. Interim WHO clinical staging of HIV/AIS amd HIV/AIDS case definitions for surveillance. African Region; 2005.

11. Narasimhan P, Wood J, MacIntyre CR, Mathai D. Risk factors for tuberculosis: review article. Pulmonary Medicine 2013;1-11. https://doi.org/10.1155/2013/828939

12. Mama M, Manilal A, Tesfa H, Mohammed H, Erbo E. Prevalence of pulmonary tuberculosis and associated factors among HIV positive patients attending antiretroviral therapy clinic at Arba Minch General Hospital, Southern Ethiophia. Open Microbiol J 2018;12:163-71.

13. Negussie A, Debalke D, Belachew T, Tadesse F. Tuberculosis coinfection and its associated factors among people living with HIV/AIDS attending antiretroviral therapy clinic in souther Ethiophia: a facility-based retrospective study. BMC REs Notes 2018;11:417. 
14. Tiwari BR, Karki S, Ghimire P, Sharma B, Malla S. Factors associated with high prevalence of pulmonary tuberculosis in HIV-infected people visiting for assessment of eligibility for highly active antiretroviral therapy in Kathmandu, Nepal. WHO South-East Asia J Public Heal 2012;1:404-11.

15. Kibret KT, Yalew AW, Belaineh BG, Asres MM. Determinant factors associated with occurrence of tuberculosis among adult people living with HIV after antiretroviral treatment initiation in addis ababa, ethiopia: a case control study. PLoS One 2013;8:1-8.

16. Belay A, Alamrew Z, Be Y, Tegegne B, Tiruneh G, Feleke A. Magnitude and correlates of tuberculosis among HIV patients at felege hiwot referral hospital, bahir dar city, northwest ethiopia. Clin Med Res 2013;2:77-83.

17. Roselinda, Setiawaty V. The stages of HIV infection and the risk of opportunistic tuberculosis infection. Health Sci J Indonesia 2015;6:121-5.

18. Awadalla H, El-Samani F, Soghaier MA, Makki M. Risk factors with the development of tuebrculosis among HIV-infected patients in Khartoum in 2010. AIMS Public Health 2010;2:784-92.

19. Tesfaye B, Alebel A, Gebrie A, Zegeye A, TEsema C, Kassie B. The twin epidemics: prevalence of TB/HIV co-infection and its associated factors in Ethiophia; a systematic review and metaanalysis. PLos One 2018;13:e0203986.

20. Carvalho BMD, Monteiro AJ, Nefro RDJP, Grangeiro TB, Frota CC. Factors related to HIV/uberculosis coinfection in brazilian reference hospital. Br J Infectious Disease 2008;12:281-6.

21. Boum Y, Atwine D, Orikiriza P, Assimwe J, Page AL, Mwanga Amumpaire J, et al. Male gender is independently associated with pulmonary tuberculosis among sputum and non-sputum producers people with presumptive tuberculosis in Southwestern Uganda. BMC Infect Dis 2014;14:1-8.
22. Horton KC, MacPherson P, Houben RMGJ, White RG, Corbett EL. Sex differences in tuberculosis burden and notifications in lowand middle-income counts: a systematic review and metaanalysis. PLoS Med 2016;13:1-23.

23. Dovonou A, Kpangon A, Amidou S, Dansou S, Attinssounon C, Keke $\mathrm{R}$, et al. Risk factors for pulmonary tuberculosis treatment failure in rural settings in Benin, West Africa: a cohort study. Afr J Respir Med 2017;12:1-4.

24. Keizer ST, Langendam MMW, Van Deutekom H, Coutinho RA, Van Ameijden EJC. How does tuberculosis relate to HIV positive and HIV negative drug users? J Epidemiol Community Health 2000;54:64-8.

25. Ghaffari Fam S, Hosseini SR, Heydari H, Vaseghi Amiri R, Daemi A, Sarbazi E, et al. Epidemiological patterns of tuberculosis disease in the Babol, Iran. J Anal Res Clin Med 2015;3:164-9.

26. Chang CA, Meloni ST, Eisen G, Chaplin B, Akande P, Okonkwo P, et al. Tuberculosis incidence and risk factors among human immunodeficiency virus (HIV)-infected adults receiving antiretroviral therapy in a large HIV program in nigeria. Open Forum Infect Dis 2015;2:1-11.

27. Sutariya SB, Shah HM, Patel DA, Dandge VA. Tuberculosis in patients living with HIV/AIDS: types and its relation to CD4 count. Natl J Med Res 2015;5:75-8.

28. Sudre P, Hirschel B, Toscani L, Ledergerber B, der HL. Risk factors for tuberculosis among HIV-infected patients in switzerland. Eur Respir J 1996;9:279-83.

29. Ellis PK, Martin WJ, Dodd PJ. CD4 count and tuberculosis risk in HIV-positive adults not on ART: a systematic review and metaanalysis. Peer J 2017;5:1-15.

30. Swarna NY. A review of tuberculosis research in malaysia. Med J Malaysia 2014;69:88-102.

31. Gjergji M, Bushati J, Harxhi A, Hafizi H, Pipero P. Tuberculosis in HIV/AIDS patients. Biom Biostat Int 2018;7:432-7. 